Rabaska

Revue d'ethnologie de l'Amérique française

\title{
Les Croix de chemin au temps du bon Dieu
}

Volume 6, 2008

URI : https://id.erudit.org/iderudit/019987ar

DOI : https://doi.org/10.7202/019987ar

Aller au sommaire du numéro

Éditeur(s)

Société québécoise d'ethnologie

ISSN

1703-7433 (imprimé)

1916-7350 (numérique)

Découvrir la revue

Citer ce document

(2008). Les Croix de chemin au temps du bon Dieu. Rabaska, 6, 109-109.

https://doi.org/10.7202/019987ar d'utilisation que vous pouvez consulter en ligne.

https://apropos.erudit.org/fr/usagers/politique-dutilisation/ 


\section{Points de vue / livre}

\section{Les Croix de chemin au temps du bon Dieu}

L'éditrice Julia Duchastel et la photographe Vanessa Oliver-Lloyd ont fait un beau livre auquel elles ont donné le titre évocateur de la désuétude : Les Croix de chemin au temps du bon Dieu. Marie-Thérèse Cloître, maître de conférence d'histoire contemporaine et chercheur associé au Centre de recherche bretonne et celtique, propose à Rabaska son point de vue sur ce patrimoine religieux qu'elle aborde dans le contexte d'un paysage culturel différent du sien mais apparenté. Diane Joly, doctorante en histoire de l'art à l'Université du Québec à Montréal, voit pour sa part dans ce livre une invitation à la redécouverte des croix de chemin par leurs héritiers.

Les Croix de chemin au temps du bon Dieu Photographies : Vanessa Oliver-Lloyd. Recherche et rédaction : Julia Dushastel Préface : Jean Simard. Propos et poésie : Bernard Arcand, Jean Bédard, Léandre Bergeron, Serge Bouchard, Raôul Duguay, Claude Gagnon, Michel Garneau, Jacques Gauthier, Marguerite Lescop, Hélène Pedneault, Sylvain Rivière, Claude Turmel, Claire Varin. Outremont (Québec), Les Éditions du Passage, 2007, 224 p. ISBN 978-2-922892-28-4.

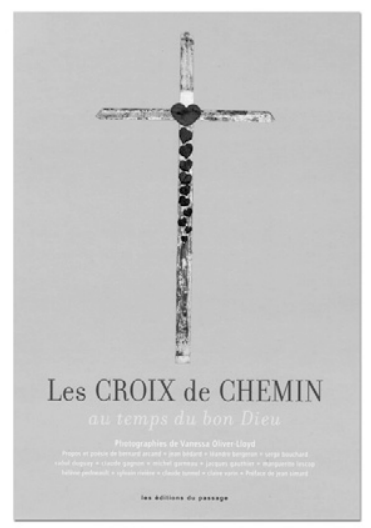

